\title{
Pengaruh Keterampilan Kerja, Team Work, dan Motivasi terhadap Kinerja Karyawan Bagian Produksi pada Art Shop Cahaya Silver di Celuk, Gianyar
}

\author{
I Wayan Gede Indra Parta ${ }^{(1)}$ \\ I Gede Aryana Mahayasa ${ }^{(2)}$ \\ (1)(2) Fakultas Ekonomi Bisnis dan Pariwisata Universitas Hindu Indonesia \\ e-mail:dedemosher@gmail.com
}

\begin{tabular}{|l|l|l|} 
Diterima: 13 Desember 2020 & Direvisi: 27 Desember 2020 & Disetujui: 4 Januari 2021
\end{tabular}

\begin{abstract}
Employee performance is the work of an individual from a plan. The purpose of this study was to determine the effect of work skills, teamwork, and motivation on the performance of production employees at the Cahaya Silver Art Shop in Celuk, Gianyar. This research was conducted at the Cahaya Silver Art Shop in Celuk, Gianyar. The number of samples taken was 32 employees, with a saturated sampling method. The research instrument was tested by validity and reliability tests. The analysis technique used is multiple linear regression. The influence of work skills, teamwork, and motivation on the performance of employees in the production department at the Cahaya Silver Art Shop in Celuk, Gianyar with the t-calculated value of each variable including work skills (X1) 2.172 and t-table value of 1.701 when compared, the t-count value is greater than t-table and t-count values are in the rejection area of Ho, teamwork (X2) 2,342 and t-table value 1.701, motivation (X3) 3,935 and t-table value 1.701 The results of the f-test show that there are the influence of work skills, teamwork, and motivation on the performance of production employees at the Cahaya Silver Art Shop in Celuk, Gianyar.
\end{abstract}

Keywords: work skills, team work, motivation, employee performance

\begin{abstract}
ABSTRAK
Kinerja karyawan adalah hasil kerja suatu individu dari sebuah perencanaan. Tujuan penelitian ini adalah untuk mengetahui pengaruh ketrampilan kerja, teamwork, dan motivasi terhadap kinerja karyawan bagian produksi pada Art Shop Cahaya Silver di Celuk, Gianyar. Penelitian ini di lakukan pada Art Shop Cahaya Silver di Celuk, Gianyar. Jumlah sampel yang diambil sebanyak 32 karyawan, dengan metode sampling jenuh. Instrumen penelitian diuji dengan uji validitas serta uji reliabilitas. Teknik analisis yang digunakan adalah regresi linier berganda. Pengaruh ketrampilan kerja, teamwork, dan motivasi terhadap kinerja karyawan bagian produksi pada Art Shop Cahaya Silver di Celuk, Gianyar dengan nilai thitung masing-masing variabel di antaranya ketrampilan kerja (X1) 2,172 dan nilai t-tabel 1,701 jika dibandingkan maka nilai t-hitung lebih besar dari nilai t-tabel dan t-hitung berada pada daerah penolakan Ho, teamwork (X2) 2,342 dan nilai t-tabel 1,701, motivasi (X3) 3,935 dan nilai t-tabel 1,701 Hasil uji f-test menunjukan bahwa terdapat pengaruh antara ketrampilan kerja, teamwork, dan motivasi terhadap kinerja karyawan bagian produksi pada Art Shop Cahaya Silver di Celuk, Gianyar.
\end{abstract}

Kata kunci: ketrampilan kerja, team work, motivasi, kinerja karyawan 


\section{Pendahuluan}

Karyawan merupakan bagian penting dalam sebuah perusahaan karena tanpa kehadiran karyawan tentu perusahaan tidak dapat berjalan. Ketika sebuah perusahaan memiliki karyawan yang baik, hal tersebut mempengaruhi tingkat produktivitas kearah yang positif begitu pula sebaliknya. Untuk mencapai produktivitas perusahaan yang maksimal, tentu perusahaan harus memiliki karyawan dengan kinerja yang mumpuni, kinerja dipengaruhi beberapa faktor seperti keterampilan yang dimiliki setiap individu, motivasi dari dalam diri individu dan atasan serta teamwork antar karyawan.

Menurut Wibowo dalam Suwati (2013) kinerja merupakan implementasi dari perancanaan yang telah disusun tersebut. Implementasi kinerja dilakukan oleh sumber daya manusia yang memiliki kemampuan, kompetensi, motivasi dan kepentingan. Sedangkan menurut Schriber dalam Marpaung (2014) performance berakar pada kata to perform, yang berarti melakukan, menjalankan, melaksanakan dan memenuhi atau menjalankan kewajiban. Faktor-faktor yang berpengaruh terhadap kinerja adalah keterampilan kerja, teamwork, motivasi.

Menurut Hasibuan dalam Istikomah dkk (2014) keterampilan kerja merupakan kemampuan sesorang dalam menyelesaikan tugas yang ditugaskan kepadanya. Tolo dkk (2016) berpendapat bahwa terdapat hubungan antara keterampilan kerja dengan kinerja dimana dengan memiliki keahlian atau keterampilan dalam bekerja akan meningkatkan kinerja pegawai. Pernyataan ini didukung oleh penelitian yang dilakukan oleh Suhartini (2017) yang menyatakan bahwa usaha yang sukses harus didukung dengan karyawan yang terampil dalam menjalankan pekerjannya.

Marpaung (2014) menyatakan bahwa teamwork berpengaruh positif dan signifikan terhadap kinerja karyawan, hal ini didasari karena teamwork tidak lepas kerjasama dari pegawai yang ada untuk bekerja dan teamwork pegawai merupakan suatu falsafah yang didasari oleh pandangan hidup sebagai nilai-nilai yang menjadi sifat manusia. Pernyataan ini didukung oleh penelitian yang dilakukan oleh Safiansyah dkk (2017) yang menyatakan bahwa teamwork berpengaruh positif dan signifikan terhadap kinerja karyawan. Sedangkan menurut Wulandari, dkk (2020), teamwork juga akan meningkatkan kepuasan kerja karyawan, sehingga akan meningkatkan kinerja karyawan itu sendiri.

Menurut Pamela dkk (2015) motivasi adalah memberikan bimbingan yang tepat atau arahan, sumber daya dan imbalan agar mereka terinspirasi dan tertarik untuk bekerja dengan cara yang anda inginkan. Sedangkan menurut Chukwuma dkk (2014) motivasi adalah proses membangkitkan perilaku, mempertahankan kemajuan perilaku, dan menyalurkan perilaku tindakan yang spesifik. menurut Vroom dalam Murti (2013) motivasi merupakan akibat dari suatu hasil yang 
ingin dicapai oleh seseorang dan perkiraan yang bersangkutan bahwa tindakannya akan mengarah kepada hasil yang diinginkannya.

Art Shop Cahaya Silver adalah salah satu perusahaan manufaktur di Bali, bergerak di bidang pembuatan kerajinan perak dan terletak di desa Celuk, Kecamatan Sukawati, Kabupaten Gianyar. Sebagai perusahaan manufaktur, tentu pihak manajemen harus sigap mengingat perusahaan tidak bisa mencapai target untuk memenuhi kebutuhan pasar, apabila hal tersebut terus terjadi dan berulang, maka margin yang didapat akan menurut dan hal tersebut bisa membuat operasional perusahaan tidak lancar karena perusahaan harus mengeluarkan biaya perawatan barang selain biaya gaji karyawan dan mempersulit perusahaan mencapai performa maksimalnya. Tujuan dari penelitian ini adalah untuk mengetahui pengaruh ketrampilan kerja, teamwork, dan motivasi terhadap kinerja karyawan baik secara parsial dan simultan pada bagian poduksi pada Art Shop Cahaya Silver di Celuk, Gianyar.

\section{Telaah Literatur dan Kajian Pustaka}

\section{Kinerja Karyawan}

Menurut Wibowo dalam Suwati (2013) kinerja merupakan implementasi dari perancanaan yang telah disusun tersebut. Implementasi kinerja dilakukan oleh sumber daya manusia yang memiliki kemampuan, kompetensi, motivasi dan kepentingan. Sedangkan menurut Schriber dalam Marpaung (2014) performance berakar pada kata to perform, yang berarti melakukan, menjalankan, melaksanakan dan memenuhi atau menjalankan kewajiban. Sedangkan menurut Sedarmayanti dalam Istikomah dkk (2014) kinerja adalah hasil kerja seorang pekerja, sebuah proses manajemen atau suatu organisasi secara keseluruhan, dimana hasil kerja tersebut harus dapat ditunjukkan buktinya secara konkrit dan dapat diukur.

\section{Keterampilan Kerja}

Menurut Hasibuan dalam Istikomah dkk (2014) keterampilan kerja merupakan kemampuan sesorang dalam menyelesaikan tugas yang ditugaskan kepadanya. menurut Wahyudi dalam Istikomah dkk (2014) keterampilan kerja yaitu kecakapan atau kemahiran untuk melakukan sesuatu pekerjaan yang hanya diperoleh dari praktek, baik yang melalui latihan praktek maupun melalui pengalaman. Sedangkan menurut Pesiwarissa dalam Polak (2012) keterampilan kerja adalah para karyawan dalam menduduki jabatannya mempunyai, kemampuan keterampilan secara teknis, keterampilan dalam hubungan kemanusiaan, keterampilan secara konsepsional

\section{Teamwork}

Menurut Dishon and O’Leary dalam Marpaung (2014) menyatakan bahwa teamwork adalah "group of two five students who are tied totgether by a common purpose to complete a task 
and to include every group members". Bene dan Seats dalam Marpaung (2014) menegaskan bahwa premis mayor dalam suatu tim adalah bahwa setiap orang dalam tim kerja harus berfungsi sebagai pemain yang kooperatifdan produktif untuk menuju tercapainya hasil yang diinginkan. Dengan sangat menekankan pentingnya kohesivitas.

\section{Motivasi Kerja}

Menurut Pamela dkk (2015) motivasi adalah memberikan bimbingan yang tepat atau arahan, sumber daya dan imbalan agar mereka terinspirasi dan tertarik untuk bekerja dengan cara yang anda inginkan. Sedangkan menurut Chukwuma dkk (2014) motivasi adalah proses membangkitkan perilaku, mempertahankan kemajuan perilaku, dan menyalurkan perilaku tindakan yang spesifik, dan menurut Vroom dalam Murti (2013) motivasi merupakan akibat dari suatu hasil yang ingin dicapai oleh seseorang dan perkiraan yang bersangkutan bahwa tindakannya akan mengarah kepada hasil yang diinginkannya.

\section{Metode Penelitian}

Desain penelitian yang digunakan dalam penelitian ini adalah desain asosiatif yaitu suatu penelitian yang meneliti pengaruh suatu variabel terhadap variabel lainnya atau mengetahui hubungan antar variabel (Sugiyono, 2013). Terdapat tiga (3) variabel bebas yaitu keterampilan kerja (X1), teamwork (X2), dan motivasi (X3) dan variabel terikat yaitu kinerja karyawan (Y).

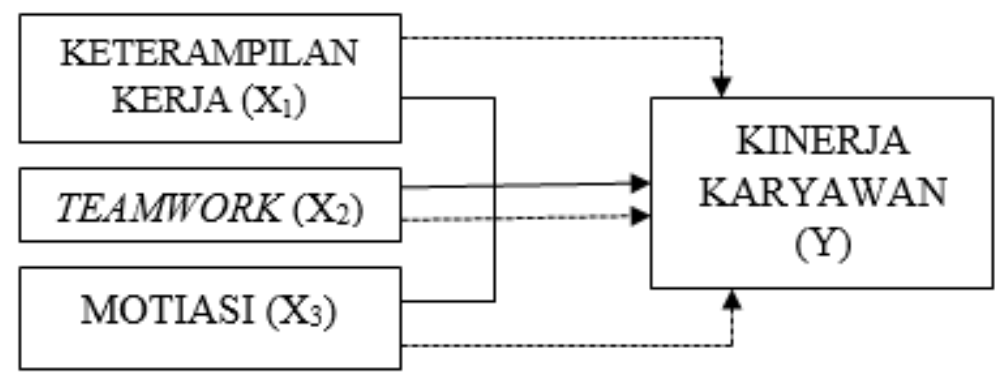

\section{Gambar 1. Kerangka Berpikir}

Di dalam penelitian ini, yang menjadi populasi penelitian adalah karyawan bagian produksi pada Art Shop Cahaya Silver di Celuk, Gianyar yaitu sebanyak 32 orang. Metode penentuan sampel yang digunakan adalah sampel jenuh sehingga seluruh anggota populasi dilibatkan dalam penelitian. Data dikumpulkan dengan metode observasi, wawancara, dokumentasi, dan kuisioner. Skala pengukuran yang digunakan dalam kuisioner adalah Skala Likert yang terdiri atas lima pilihan jawaban yaitu Sangat Tidak Setuju diberi nilai 1, Tidak Setuju diberi nilai 2, Cukup Setuju diberi nilai 3, Setuju diberi nilai 4, dan Sangat Setuju diberi nilai 5. Untuk mendapatkan jawaban atas hipotesis yang telah diajukan maka penelitian ini menggunakan analisis regresi linier berganda. Analisis regresi linier berganda untuk mengetahui hubungan sebab akibat dengan menentukan nilai 
variabel terikat (Y) dan untuk mengetahui nilai-nilai yang berhubungan dengan variabel bebas (X), dengan menggunakan rumus statistik.

\section{Hasil Penelitian dan Pembahasan}

Tabel 1. Hasil Uji Validitas dan Reliabilitas

\begin{tabular}{|c|c|c|c|c|c|}
\hline \multirow{2}{*}{ Variabel } & \multirow{2}{*}{ Pernyataan } & \multicolumn{2}{|c|}{ Validitas } & \multicolumn{2}{|c|}{$\begin{array}{r}\text { Reliabilitas } \\
\end{array}$} \\
\hline & & Koefisien Korelasi & Ket. & Cronbach's Alpha & ket. \\
\hline \multirow{16}{*}{ Keterampilan Kerja (X1) } & $\mathrm{X} 1.1$ & 0,780 & Valid & \multirow{16}{*}{0,973} & \multirow{16}{*}{ Reliabel } \\
\hline & $\mathrm{X} 1.2$ & 0,818 & Valid & & \\
\hline & $\mathrm{X} 1.3$ & 0,872 & Valid & & \\
\hline & $\mathrm{X} 1.4$ & 0,881 & Valid & & \\
\hline & $\mathrm{X} 1.5$ & 0,822 & Valid & & \\
\hline & $\mathrm{X} 1.6$ & 0,894 & Valid & & \\
\hline & $\mathrm{X} 1.7$ & 0,836 & Valid & & \\
\hline & $\mathrm{X} 1.8$ & 0,881 & Valid & & \\
\hline & $\mathrm{X} 1.9$ & 0,780 & Valid & & \\
\hline & $\mathrm{X} 1.10$ & 0,827 & Valid & & \\
\hline & $\mathrm{X} 1.11$ & 0,870 & Valid & & \\
\hline & $\mathrm{X} 1.12$ & 0,881 & Valid & & \\
\hline & $\mathrm{X} 1.13$ & 0,824 & Valid & & \\
\hline & $\mathrm{X} 1.14$ & 0,792 & Valid & & \\
\hline & $\mathrm{X} 1.15$ & 0,929 & Valid & & \\
\hline & $\mathrm{X} 1.16$ & 0,894 & Valid & & \\
\hline \multirow{10}{*}{ Teamwork (X2) } & $\mathrm{X} 2.1$ & 0,895 & Valid & \multirow{10}{*}{0,973} & \multirow{10}{*}{ Reliabel } \\
\hline & $\mathrm{X} 2.2$ & 0,881 & Valid & & \\
\hline & $\mathrm{X} 2.3$ & 0,873 & Valid & & \\
\hline & $\mathrm{X} 2.4$ & 0,904 & Valid & & \\
\hline & $\mathrm{X} 2.5$ & 0,927 & Valid & & \\
\hline & $\mathrm{X} 2.6$ & 0,902 & Valid & & \\
\hline & $\mathrm{X} 2.7$ & 0,850 & Valid & & \\
\hline & $\mathrm{X} 2.8$ & 0,859 & Valid & & \\
\hline & X2.9 & 0,918 & Valid & & \\
\hline & $\mathrm{X} 2.10$ & 0,959 & Valid & & \\
\hline \multirow{12}{*}{ Motivasi $\left(\mathrm{X}_{3}\right)$} & X3.1 & 0,921 & Valid & \multirow{12}{*}{0,981} & \multirow{12}{*}{ Reliabel } \\
\hline & $\mathrm{X} 3.2$ & 0,890 & Valid & & \\
\hline & X3.3 & 0,933 & Valid & & \\
\hline & X3.4 & 0,918 & Valid & & \\
\hline & X3.5 & 0,909 & Valid & & \\
\hline & X3.6 & 0,931 & Valid & & \\
\hline & X3.7 & 0,886 & Valid & & \\
\hline & X3.8 & 0,884 & Valid & & \\
\hline & X3.9 & 0,908 & Valid & & \\
\hline & X3.10 & 0,929 & Valid & & \\
\hline & X3.11 & 0,918 & Valid & & \\
\hline & $\mathrm{X} 3.12$ & 0,928 & Valid & & \\
\hline \multirow{11}{*}{ Kinerja Karyawan (Y) } & Y.1 & 0,858 & Valid & \multirow{11}{*}{0,955} & \multirow{11}{*}{ Reliabel } \\
\hline & Y.2 & 0,807 & Valid & & \\
\hline & Y.3 & 0,881 & Valid & & \\
\hline & Y.4 & 0,845 & Valid & & \\
\hline & Y.5 & 0,853 & Valid & & \\
\hline & Y.6 & 0,802 & Valid & & \\
\hline & Y.7 & 0,805 & Valid & & \\
\hline & Y.8 & 0,860 & Valid & & \\
\hline & Y.9 & 0,831 & Valid & & \\
\hline & Y.10 & 0,837 & Valid & & \\
\hline & Y.11 & 0,840 & Valid & & \\
\hline
\end{tabular}

Sumber : data diolah, 2020 
Berdasarkan Tabel 1 diperoleh bahwa semua instrumen yang digunakan untuk mengukur variabel bebas dan terikat semuanya valid dan reliabel dengan nilai Cronbach`s Alpha di atas 0,6.

Tabel 2. Karakteristik Responden

\begin{tabular}{lcc}
\hline Kategori & Jumlah (orang) & Persentase (\%) \\
\hline Jenis Kelamin : & 20 & \\
Laki-Laki & 12 & 62,5 \\
Perempuan & $\mathbf{3 2}$ & 37,5 \\
Total & & $\mathbf{1 0 0}$ \\
\hline Usia : & - & - \\
20 Tahun & 11 & 34,4 \\
20-30 Tahun & 13 & 40,6 \\
- - 40 bulan & 8 & 25,0 \\
T0 Tahun & $\mathbf{3 2}$ & $\mathbf{1 0 0}$ \\
Total & & \\
Pendidikan : & 5 & 15,6 \\
Sarjana & 2 & 6,3 \\
Diploma & 23 & 71,9 \\
SMA/SMK & 2 & 6,3 \\
SMP & - & - \\
SD & $\mathbf{3 2}$ & $\mathbf{1 0 0}$ \\
Total & & \\
\hline
\end{tabular}

Sumber : data diolah, 2020

Responden dalam penelitian ini terbagi dalam tiga kategori yaitu berdasarkan jenis kelamin, usia, dan pendidikan yang dapat dilihat pada Tabel 2. Berdasarkan jenis kelamin dapat diketahui bahwa sebagian besar responden adalah berjenis kelamin laki-laki yaitu sebanyak 62,5\% dan sisanya 37,5\% adalah perempuan. Hal itu karena sebagian besar karyawan yang bekerja pada Art Shop Cahaya Silver adalah para pengrajin perak yang mana didominasi oleh kaum laki-laki. Berdasarkan usia dapat diketahui bahwa 40,6\% yang bekerjapada Art Shop Cahaya Silver adalah yang berusia 31-40 tahun, 34,4\% yang berusia 20-30 tahun, dan sisanya $25 \%$ yang berusia $>40$ tahun. Hal ini karena sebagian besar karyawan yang bekerja pada Art Shop Cahaya Silver adalah pengrajin yang sudah berkerluarga serta memiliki anak. Berdasarkan pendidikannya dapat diketahui bahwa 71,9\% karyawan pada Art Shop Cahaya Silver adalah yang bependidikan SMA/SMK, 15,6\% yang berpendidikan Sarjana, dan 6,3\% yang berpendidikan Diploma dan SMP. Hal ini karena karyawan pada Art Shop Cahaya Silver adalah kebanyakan lulusan SMK/SMK yang tidak melanjutkan pendidikannya tetapi lebih memilih untuk mengembangkan kemampuannya atau meneruskan warisan keluarga bekerja sebagai pengrajin perak.

Dari Tabel 3 dapat dilihat bahwa nilai Asymp. Sig. (2-tailed) adalah 0,200. Nilai tersebut lebih besar dari 0,05 yang berarti dapat dikatakan bahwa variabel tersebut adalah berdistribusi normal. Pada Tabel 4 menunjukkan nilai Tolerance lebih besar dari 0,10 serta nilai VIF lebih kecil dari 10. Maka dapat disimpulkan bahwa dalam model regresi tidak terjadi multikolinearitas. Dari Tabel 5 dapat diketahui bahwa nilai signifikansi antara variabel independen dengan nilai absolut 
residualnya (ABS_RES) lebih besar dari 0,05. Hal ini berarti tidak terjadi gejala heteroskedastisitas pada model regresi.

\section{Tabel 3. Hasil Uji Normalitas}

One-Sample Kolmogorov-Smirnov Test

\begin{tabular}{llr}
\hline & & Unstandardized Residual \\
\hline $\mathrm{N}$ & & 32 \\
Normal Parameters & Mean & 0 \\
& Std. Deviation & 1.99763165 \\
& Absolute & 0.109 \\
Most Extreme Differences & Positive & 0.109 \\
& Negative & -0.061 \\
Test Statistic & & 0.109 \\
Asymp. Sig. (2-tailed) & & $.200^{\mathrm{c}, \mathrm{d}}$ \\
\hline
\end{tabular}

Sumber: data diolah, 2020

Tabel 4. Hasil Uji Multikolinearitas

\begin{tabular}{lcc}
\hline Variabel Bebas & Tolerance & Nilai VIF \\
\hline Keterampilan Kerja & 0,205 & 4,885 \\
Teamwork & 0,215 & 4,651 \\
Motivasi & 0,299 & 3,349 \\
\hline
\end{tabular}

Sumber: data diolah, 2020

Tabel 5. Hasil Uji Heteroskedastisitas

\begin{tabular}{lccc}
\hline \multicolumn{1}{c}{ Variabel } & B & t-hitung & Sig. \\
\hline Konstan & .481 & .313 & .756 \\
Keterampilan Kerja & .073 & 1.388 & .176 \\
Teamwork & -.053 & -.777 & .444 \\
Motivasi & -.033 & -.636 & .530 \\
\hline
\end{tabular}

Sumber : data diolah, 2020

Pengaruh keterampilan kerja, teamwork, dan motivasi terhadap kinerja karyawan dapat diketahui secara nyata dengan menggunakan analisis regresi linier barganda, dapat dilihat pada Tabel 6.

\section{Tabel 6. Hasil Analisis Regresi Linier Berganda}

\begin{tabular}{|c|c|c|c|c|c|c|}
\hline \multirow{2}{*}{\multicolumn{2}{|c|}{ Model }} & \multicolumn{2}{|c|}{ Unstandardized Coefficients } & \multirow{2}{*}{$\begin{array}{c}\text { Standardized Coefficients } \\
\text { Beta }\end{array}$} & \multirow{2}{*}{$\mathrm{t}$} & \multirow{2}{*}{ Sig. } \\
\hline & & B & Std. Error & & & \\
\hline \multirow{4}{*}{1} & (Constant) & 8.158 & 2.461 & & 3.315 & .003 \\
\hline & Keterampilan Kerja & .184 & .085 & 284 & 2.172 & .038 \\
\hline & Teamwork & .255 & .109 & .299 & 2.342 & .027 \\
\hline & Motivasi & .322 & .082 & .426 & 3.935 & .000 \\
\hline
\end{tabular}

Sumber: data diolah, 2020

Berdasarkan Tabel 6, maka persamaan regresi linier berganda akan menjadi:

$$
\mathrm{Y}=8,158+0,184 \mathrm{X} 1+0,255 \mathrm{X} 2+0,322 \mathrm{X} 3
$$

Berdasarkan persamaan regresi linier berganda di atas, diperoleh persamaan garis regresi yang memberikan informasi bahwa, a $=8,158$, artinya apabila tidak ada perhatian terhadap keterampilan kerja, teamwork dan motivasi atau nilainya tetap, maka besarnya kinerja karyawan 
adalah 8,158. b1 $=0,184$, artinya apabila teamwork dan motivasi dianggap konstan atau nilainya tetap, maka meningkatnya keterampilan kerja akan diikuti oleh meningkatnya kinerja karyawan sebesar 0,184. b2 =0,255, artinya apabila keterampilan kerja dan motivasi dianggap konstan atau nilainya tetap, maka meningkatnya teamwork akan diikuti oleh meningkatnya kinerja karyawan sebesar 0,255. b3 =0,322 artinya apabila keterampilan kerja dan teamwork dianggap konstan atau nilainya tetap, maka meningkatnya motivasi akan diikuti oleh meningkatnya kinerja karyawan sebesar 0,322 .

Nilai koefisien determinasi (R2) berdasarkan Tabel 7 hasil perhitungan dengan SPSS diperoleh 0,902 . Ini berarti besarnya kontribusi atau sumbangan pengaruh antara keterampilan kerja, teamwork, dan motivasi terhadap kinerja karyawan adalah 90,2\% sedangkan sisanya 9,8\% dipengaruhi oleh variabel lain lainnya yang tidak dibahas dalam penelitian ini, yaitu seperti kepemimpinan, disiplin kerja, komunikasi dan lain sebagainya.

\section{Tabel 7. Analisis Koefisien Determinasi}

Model Summary ${ }^{b}$

\begin{tabular}{rcccc}
\hline Model & $\mathrm{R}$ & R Square & Adjusted R Square & Std. Error of the Estimate \\
\hline 1 & $.950^{\mathrm{a}}$ & .902 & .891 & 2.10193 \\
\hline
\end{tabular}

Sumber: data diolah, 2020

Uji signifikansi parsial dengan uji-t digunakan untuk menguji pengaruh antara keterampilan kerja, teamwork, dan motivasi terhadap kinerja karyawan secara parsial adalah signifikan atau hanya diperoleh secara kebetulan. Berdasarkan Tabel 6, dapat dinyatakan bahwa:

1. Pengaruh Keterampilan Kerja terhadap Kinerja Karyawan

Keterampilan kerja berpengaruh positif dan signifikan terhadap kinerja karyawan. Hal ini dapat dilihat dari nilai koefisien keterampilan kerja 0,184 dan nilai t1-hitung 2,172 lebih besar dari nilai t-tabel 1,701, dan t-hitung berada pada daerah penolakan H0, Sehingga dapat disimpulkan bahwa keterampilan kerja secara parsial mempunyai pengaruh yang positif dan signifikan terhadap kinerja karyawan. Maka hipotesis yang menyatakan secara parsial keterampilan kerja berpengaruh positif dan signifikan terhadap kinerja karyawan pada Art Shop Cahaya Silver dapat diterima. Hal ini mendukung penelitian sebelumnya oleh Tolo dkk (2016) yang menemukan bahwa keterampilan kerja berpengaruh positif dan signifikan terhadap kinerja pegawai pada Dinas Pemuda dan Olahraga (Disopora) Manado.

\section{Pengaruh Teamwork terhadap Kinerja Karyawan}

Teamwork berpengaruh positif dan signifikan terhadap Kinerja Karyawan. Hal ini dapat dilihat dari nilai koefisien teamwork 0,255 dan nilai t2-hitung 2,342 lebih besar dari nilai t-tabel 1,701, dan t-hitung berada pada daerah penolakan H0, oleh karena itu H0 ditolak dan Ha diterima. 
Sehingga dapat disimpulkan bahwa teamwork secara parsial mempunyai pengaruh yang positif dan signifikan terhadap kinerja karyawan. .Maka hipotesis yang menyatakan secara parsial teamwork berpengaruh positif dan signifikan terhadap kinerja karyawan pada Art Shop Cahaya Silver dapat diterima. Hal ini mendukung penelitian sebelumnya oleh Syafiansyah (2017) yang menemukan bahwa teamwork berpengaruh positif dan signifikan terhadap kinerja pegawai pada PT.PLN (Persero) Cabang Banda Aceh.

3. Pengaruh Motivasi terhadap Kinerja Karyawan

Motivasi berpengaruh positif dan signifikan terhadap kinerja. Hal ini dapat dilihat dari nilai koefisien motivasi 0,322 dan nilai t3-hitung 3,935 lebih besar dari nilai t-tabel 1,701, dan t-hitung berada pada daerah penolakan H0, oleh karena itu H0 ditolak dan Ha diterima. Sehingga dapat disimpulkan bahwa motivasi secara parsial mempunyai pengaruh yang positif dan signifikan terhadap kinerja karyawan. Maka hipotesis yang menyatakan secara parsial motivasi berpengaruh positif dan signifikan terhadap kinerja karyawan pada Art Shop Cahaya Silver dapat diterima. Hal ini mendukung penelitian sebelumnya oleh Makian dkk (2016) yang menemukan bahwa motivasi kerja memiliki pengaruh positif dan signifikan terhadap kinerja karyawan pada Karyawan PT PCI Elektronik International.

Tabel 8. Hasil Analisis Uji F

\begin{tabular}{llccccc}
\hline Model & & Sum of Squares & df & Mean Square & F & Sig. \\
\hline \multirow{2}{*}{1} & Regression & 1137.762 & 3 & 379.254 & 85.841 & $.000^{\mathrm{b}}$ \\
& Residual & 123.706 & 28 & 4.418 & & \\
& Total & 1261.469 & 31 & & & \\
\hline
\end{tabular}

Sumber: data diolah, 2020

Hasil uji F untuk mengetahui pengaruh secara simultan variabel bebas terhadap variabel terikat, seperti dinyatakan Tabel 8, keterampilan kerja, teamwork dan motivasi berpengaruh positif dan signifikan secara simultan terhadap kinerja karyawan. Hal ini dapat dilihat dari nilai F-hitung 85,841 lebih besar dari nilai F-tabel 2,95, dan signifikan di 0,000. Maka hipotesis yang menyatakan secara simultan keterampilan kerja, teamwork, dan motivasi berpengaruh positif dan signifikan secara simultan terhadap kinerja karyawan pada Art Shop Cahaya Silver diterima. Hal ini mendukung penelitian sebelumnya oleh Makian dkk (2016) yang menemukan bahwa pelatihan kerja dan motivasi kerja berpengaruh positif dan signifikan terhadap kinerja karyawan Bagian PT. PCI Elektronik International, serta penelitian Syafiansyah (2017) yang menyatakan teamwork berpengaruh positif dan signifikan terhadap kinerja pegawai pada PT.PLN (Persero) Cabang Banda Aceh. 


\section{Simpulan}

Berdasarkan rumusan masalah dan analisis data yang telah dilakukan serta pembahasan yang dikemukakan pada bab sebelumnya, maka kesimpulan dari penelitian ini adalah keterampilan kerja berpengaruh positif dan signifikan terhadap kinerja karyawan, teamwork berpengaruh positif dan signifikan terhadap kinerja karyawan, motivasi berpengaruh positif dan signifikan terhadap kinerja karyawan, keterampilan kerja, teamwork, dan motivasi secara simultan berpengaruh positif dan signifikan terhadap kinerja karyawan. Saran-saran yang dapat diajukan berkaitan dengan penelitian ini adalah manajemen Art Shop Cahaya Silver diharapkan dapat membuat perencanaan dengan melibatkan karyawan terutama bagian produksi untuk dapat lebih mengembangkan desaindesain yang sudah ada sehingga dapat meningkatkan kualitas serta selera pasar kedepannya. Untuk meningkatkan kekompakan karyawan, manajemen Art Shop Cahaya Silver diharapkan dapat mengadakan gathering dengan para karyawannya. Dengan adanya gathering seperti berekreasi, bermain games serta melakukan kegiatan bersama akan membuat karyawan lebih mengenal satu sama lain dan lebih dekat secara emosional. Untuk meningkatkan motivasi karyawan, Pimpinan Art Shop Cahaya Silver diharapkan dapat selalu mendengarkan keluhan-keluhan yang dirasakan karyawan serta menanggapi keluhan tersebut agar tidak berlarut-larut. Adanya perhatian dari pimpinan akan membuat karyawan merasa bahwa dirinya penting dan mengeluarkan kemampuan terbaiknya untuk perusahaan.

\section{Daftar Pustaka}

Adrianto, Sopan. 2011. Pengaruh Keterampilan Teknis, Keterampilan Sosial, Keterampilan Konseptual, Dan Keterampilan Manajerial Terhadap Kinerja Kepala Sekolah Dasar Negeri DI Wilayah Jakarta Pusat. Jurnal Manajemen Pendidikan. 1(1), pp: 289-297.

Alisyahbana, Farid. 2015. Pengaruh Kreativitas Dan Kerjasama Tim Terhadap Kinerja Pendamping UPPKH (Unit Pelaksana Program Keluarga Harapan) Kabupaten Sampang. Jurnal Neo-Bisnis.9(2), pp: 53-65.

Ambar Teguh Sulistiyani Rosidah. (2009) Manajemen Sumber Daya Manusia konsep, Teori dan pengembangan dalam konteks organisasi Publik, yogyakarta: Graha Ilmu

Anwar Prabu Mangkunegara, 2005. Evaluasi Kinerja Manajemen Sumber Daya Manusia, Refika Aditama, Bandung

Anwar Prabu Mangkunegara. (2009). Manajemen Sumber Daya Manusia Perusahaan. Bandung: PT Remaja Rosda Karya.

Anwar. 1991. Evaluasi kinerja Sumber Daya Manusia, Bandung. PT. Refika Aditama Arkola.Undang-Undang No.32 Thun 2004 Otonomi Daerah.

Dessler, Gary, 2003. MSDM, Jilid I. Jakarta PT.Indeks

Dessler. 1997 Manajemen Sumber Daya Manusia Jakarta. PT. Prenhalindo.

Dwi Priyanto. 2008. Statistical Product and Service Solution/SPSS) Mandiri Belajar, PT. Buku Kita, Jakarta

Dwiyanto. 1995. Konsep Kinerja Organisasi Publik, Jakarta, Jaya Abadi.

Foster, Bill. 2001. Pembinaan untuk Peningkatan Kinerja Karyawan.PPM : Jakarta. 
Gomes, Fouston C. 2003 Manajemen Sumber Daya Manusia, Binarupa Aksara, Jakarta.

Handoko, T.Hani. 2007. Manajemen Persero. BPFE-UGM, Jogyakarta.

Hasbullah. 2009. Dasar-dasar Ilmu Pendidikan Edisi Revisi. Jakarta: Rajawali Pers

Hasibuan, Malayu. (2014). Manajemen Sumber Daya Manusia. Jakarta: Bumi Aksara

Henry Simamora, 2004. Riset Sumber Daya Manusia, Edisi Ke-2, Cetakan Ketiga, STIE YKPN, Yogyakarta

Hidayat, Wahyu. 2014. Pengaruh Keterampilan Kerja, Kompensasi Dan Disiplin Kerja Terhadap Kinerja Perawat (Studi Kasus Rumah Sakit Islam Sultan Agung Semarang Bagian Rawat Inat Unit Umum). Diponegoro Journal of Social And Politic. 1(1), pp: 1-12.

Husain, Umar. 2001 Riset Sumber Daya Manusia. PT. Gramedia Pustaka Utama, Jakarta.

Juniantara, I Wayan dkk. 2015. Pengaruh Motivasi Dan Kepuasan Kerja Terhadap Kinerja Karyawan Koperasi Di Denpasar. E-Jurnal Ekonomi dan Bisnis Universitas Udayana. 4(9), pp: 611-628.

Kartono, Kartini. 2000. Pemimpin dan Kepemimpinan. Rajawali Jakarta.

Kumorotomo. 1995 Manajemen Kinerja Sektor Publik. Yogyakarta, UPPAM.

Mahmudi. 2005. Perilaku Organisasi Edisi 1. Jakarta Salemba Empat.

Mangkuprawira, Syafri, 2003. Manajemen Sumber Daya . Orasi Ilmiah Guru Besar Tetap.

Marpaung, Marudut. 2014. Pengaruh Kepemimpinan Dan Team Work Terhadap Kinerja Karyawan Di Koperasi Sekjen Kemendikbud Senayan Jakarta. Jurnal Ilmiah WIDYA. 2(1), pp: 33-40.

Moekijat. 1981. Latihan dan Pengembangan Pegawai. Bandung : Alimni

Murti, Harry dkk. 2013. Pengaruh Motivasi Terhadap Kinerja Pegawai Dengan Variabel Pemediasi Kepuasan Kerja Pada PDAM Kota Madiun. Jurnal Riset Manajemen dan Akutansi. 1(1), pp: $10-17$.

Nasution S 2006. Metode Penelitian. Ghalia Indonesia. Jakarta Hal 143

Nitisemito, Alex. S. 2000, Manajemen Sumber Daya Manusia dan Organisasi, Jakarta

Notoatmojo, Soekidjo, 2003. Pengembangan sumber Daya Manusia, Edisi Revisi, Penerbit Rineka Cipta, Jakarta.

Polak, Yanti Sriwulan. 2012. Pengaruh Tingkat Pendidikan, Keterampilan Kerja Dan Sikap Kerja Terhadap Prestasi Kerja Karyawan PT Bank Negara Indonesia (Persero) Tbk Cabang Makasar. Skripsi Sarjana Jurusan Manajemen Fakultas Ekonomi Dan Bisnis Universitas Hasanuddin, Makasar.

Rivai. 2004. Penilaian Prestasi Kerja Teori dan Praktek. Jakarta. PT. Ganudra Pustaka Utama. Sarwono.P. 1998. Pengukuran Efektivitas Kerja Pegawai . Andi Offset. Jogyakarta.

Sastrohadiwiryo, siswanto. 2002. Manajemen Tenaga Kerja Indonesia (Pendekatan Administrasitif dan Operasional). Jakarta: Sinar Grafika Offset.

Sedarmayanti. 2005. Manajemen Sumber Daya Manusia, Penerbit PR. Refika Aditama, Bandung. Siagian, Sondang P. 1998. Pengembangan Manajemen Sumber Daya Manusia di Indonesia. Ganesha. Bandung.

Simamora. 1995. Kebijakan Kinerja Karyawan Yogyakarta. BPFE.

Sinambela, M.Pd, Lijan Poltak. 2012. Kinerja Pegawai: Teori, Pengukuran, dan Implikasi.Yogyakarta: Graha Ilmu.

Soekidjo Notoatmojo. 2009. Pengembangan Sumber Daya Manusia. Jakarta: Rieneka Cipta.

Soeprihanto,Jhon. 2001. Penilaian Kinerja dan Pengembangan Karyawan, Edisi Pertama, Cetakan Kelima BPFE, Yogyakarta.

Stoner. 1991. Sistem Manajemen Kerja Jakarta. PT. Gramedia Pustaka Utama.

Sudjana (2003). Teknik Analisis Regresi dan Korelasi (Bagi para peneliti). Bandung:Tarsito

Sugiyono. (2012). Metode Penelitian Kombinasi. Bandung: Alfabeta.

Sugiyono. (2013). Metode Penelitian Pendidikan. Bandung: Alfabeta. 
Sugiyono. 2011. Metode Penelitian Kuantitatif, Kualitatif, dan R\&D. Cetakan 14. Bandung: Alfabeta.

Suharsimi, Arikunto. 1997. Prosedur Penelitian, Suatu Pendekatan Praktek. PT. Rineka Cipta. Jakarta.

Surya, Jen dkk. 2017. Pengaruh Kepemimpinan dan Team Work Terhadap Kinerja Pegawai Pada PT. PLN (Persero) Cabang Banda Aceh. Jurnal Ekonomi dan Manajemen Teknologi. 1(2), pp: 86-90.

Sutrisno, E. 2009. Motivasi dan Pemotivasian Dalam Manajemen, Edisi I, Cetakan I, Jakarta: Penerbit PT. Raja Grafindo Persada

Suwati, Yuli. 2013. Pengaruh Kompensasi Dan Motivasi Kerja Terhadap Kinerja Karyawan Pada PT. Tunas Hijau Samarinda. eJournal Ilmu Administrasi Bisnis. 1(1), pp: 41-55.

Umam, Khaerul. 2010. Perilaku Organisasi. Bandung: Pustaka Setia

Wulandari, N. L. A. A., Sumadi, N. K., \& Swara, N. N. A. A. V. (2020). Pengaruh Self Esteem, Empowerment, dan Team Work Terhadap Kepuasan Kerja Karyawan Pada PT. BPR TISH di Gianyar. Widya Manajemen, 2(1), 89-99. https://doi.org/10.32795/ widyamanajemen. v2i1.552 